\section{Midazolam for caudal analgesia in children: comparison with caudal bupivacaine}

In a randomized, double-blind study we have examined the analgesic efficacy of caudal administration of midazolam, bupivacaine, or a mixture of both drugs in 45 children, undergoing inguinal herniotomy. They were allocated randomly into three groups ( $n=15$ in each) to receive a caudal injection of either $0.25 \%$ bupivacaine $1 \mathrm{ml} \cdot \mathrm{kg}^{-1}$ with or without midazolam 50 $\mu \mathrm{g} \cdot \mathrm{kg}^{-1}$ or midazolam $50 \mu \mathrm{g} \cdot \mathrm{kg}^{-1}$ with normal saline 1 $\mathrm{ml} \cdot \mathrm{kg}^{-l}$. There were no differences in quality of pain relief, pastoperative behaviour or analgesic requirements between the midazolam group and the other two groups. Times to first analgesic administration (paracetamol suppositories) were longer $(P<0.001)$ in the bupivacaine-midazolam group than in the other two groups. Further, the bupivacaine-midazolam group received fewer $(P<0.05)$ doses of paracetamol than the bupivacaine group. Side effects such as motor weakness, respiratory depression or prolonged sedation were not observed in patients who received caudal epidural midazolam only. We conclude that caudal midazolam in a dose of $50 \mu \mathrm{g} \cdot \mathrm{kg}^{-1}$ provides equivalent analgesia to bupivacaine $0.25 \%$, when administered postoperatively in a volume of $1 \mathrm{ml} \cdot \mathrm{kg}^{-1}$ for children following unilateral inguinal herniotomy.

Cette étude randomisée et à double aveugle évalue l'efficacité analgésique du midazolam, de la bupivacaine ou du mélange de ces deux produits administrés par la voie caudale chez 45 enfants soumis à une herniotomie inguinale. Ils sont répartis en trois groupes $(n=15)$ pour recevoir une injection caudale

\section{Key words}

ANALGESIA: paediatric, postoperative;

ANAESTHETIC TECHNIQUES: caudal;

ANAESTHETIC, LOCAL: bupivacaine;

HYPNOTICS: benzodiazepines, midazolam.

From the Department of Anaesthesia and ICU, King Saud University, Faculty of Medicine at King Khalid University Hospital.

Address correspondence to: Dr. Mohamed Naguib, Faculty of Medicine, King Khalid University Hospital, Department of Anaesthesia (41), PO Box 7805, Riyadh 11472, Saudi Arabia. Accepted for publication 26th February, 1995. contenant soit de bupivacä̈e $0,25 \% 1 \mathrm{ml} \cdot \mathrm{kg}^{-1}$ avec ou sans midazolam $50 \mu \mathrm{g} \cdot \mathrm{kg}^{-1}$, soit de midazolam $50 \mu \mathrm{g} \cdot \mathrm{kg}^{-1}$ avec du soluté physiologique $1 \mathrm{ml} \cdot \mathrm{kg}^{-1}$. Nous ne notons pas de différence pour ce qui est de la qualité de l'analgésie, du comportement pastopératoire et des besoins en analgésiques entre le groupe midazolam et les deux autres groupes. Lintervalle précédant la première administration d'un analgésique (du paracétamol en suppositoire) est plus long $(P<0,001)$ pour le groupe bupivacaïne-midazolám que pour les deux autres groupes. De plus, nous administrons moins souvent $(P<0,05)$ de paracétamol au groupe bupivacaïne-midazolam qu'an groupe bupivacaïne. Nous concluons que le midazolam caudal à la dose de $50 \mu \mathrm{g} \cdot \mathrm{kg}^{-1}$ produit une analgésie équivalente à la bupivacaïne 0,25\% lorsquill est administré à des enfants à la période postopératoire dans un volume de $1 \mathrm{ml} \cdot \mathrm{kg}^{-1}$ après une herniotomie inguinale.

Caudal analgesia is the most commonly used regional technique for postoperative analgesia in children. ${ }^{1} \mathrm{Be}-$ cause of the side effects of bupivacaine which include motor weakness, urinary retention and cardiovascular and central nervous system toxicity, ${ }^{2,3}$ we have chosen to evaluate the use of epidural midazolam as an alternative analgesic to bupivacaine for children undergoing inguinal herniotomy.

In order to minimize side effects of local anaesthetics and to maximize analgesia of caudal epidurals, many pharmaceuticals have been administered into the epidural space. Several lines of evidence suggest that the nociceptive processing may be modulated at the level of the spinal cord by a variety of local receptor systems, including those of opioid, adrenergic, and benzodiazepine agonists. Caudal administration of morphine produces a prolonged postoperative analgesia, ${ }^{4}$ but is associated with major side effects, in particular the potential of delayed respiratory depression. ${ }^{4,5}$ Clonidine, an alpha ${ }_{2}$ adrenergic agonist, has been shown to potentiate postoperative analgesia when used in combination with local anaesthetics. ${ }^{6}$ Although the addition of clonidine to bupivacaine improved the efficacy of caudal analgesia, it was associated with prolonged sedation in children. ${ }^{7}$ Of all the agents 
used, epidural midazolam seems to show promise because of the absence of the aforementioned side effects.

The principal mechanism by which epidural midazolam provides analgesia is through the GABA-benzodiazepine system in the spinal cord. Binding sites for benzodiazepines have been demonstrated in the spinal cord $^{8,9}$ and endogenous benzodiazepine-like substances have been discovered in the human cerebrospinal fluid. ${ }^{10}$ At all levels, the highest density of binding sites was found within lamina II of the dorsal horn, ${ }^{9}$ a region which plays a prominent role in the processing of nociceptive information. Based on radioligand binding assays and electrophysiological studies, the benzodiazepine site appears to be linked to the $\mathrm{GABA}_{\mathrm{A}}$ (gamma-aminobutyric acid (gam receptor complex. ${ }^{11,12}$ Several investigators have reported that intrathecally or epidurally administered midazolam produces a dose-dependent modulation of spinal nociceptive processing in both rats ${ }^{13-15}$ and humans without respiratory depression, ${ }^{16-20}$ suggesting that some of the spinal benzodiazepine sites are associated with dorsal horn systems which encode pain-related information.

Midazolam has been used in the epidural space and as a spinal anaesthetic in humans, ${ }^{16-20}$ and has been shown to have no neurological effects. ${ }^{20,21}$

This double-blind, randomized study, was designed to compare the analgesic efficacy of caudal administration of midazolam, bupivacaine or mixture of both drugs in the treatment of pain after herniotomy in children.

\section{Methods}

Institutional Review Board approval and informed consent from parents or guardians were obtained. We studied 45 boys, ASA physical status I, who were scheduled to undergo unilateral inguinal hemiotomy. Patients were excluded from the study if a history of allergic reactions to local anaesthetics, bleeding diathesis, aspirin ingestion in the preceding week, or pre-existing neurological or spinal disease were present.

No premedication was given and all operations were carried out under general anaesthesia. Anaesthesia was induced with inhalation of nitrous oxide, oxygen and halothane. In all patients, anaesthesia was maintained with $70 \%$ nitrous oxide in oxygen and halothane delivered via an Ayre's T-piece with spontaneous ventilation. No intraoperative sedatives or opioids were administered.

At the end of surgery, patients were assigned randomly to one of three groups. Children in Group I received a caudal injection of plain $0.25 \%$ bupivacaine, $1 \mathrm{ml} \cdot \mathrm{kg}^{-1}$. Those in Group II received an identical local anaesthetic dosage mixed with midazolam $50 \mu \mathrm{g} \cdot \mathrm{kg}^{-1}$ and those in Group III received caudal midazolam $50 \mu \mathrm{g} \cdot \mathrm{kg}^{-1}$ in $0.9 \%$ sodium chloride using the same weight-related volumes. All blocks were performed by one investigator with the patient in the left lateral position, using a 23-gauge needle under sterile conditions. A small Elastoplast dressing was placed over the site of sacral hiatus in all patients. The preparation of midazolam used in this study is Dormicum ${ }^{\circledR}$ (Roche) ampoules which contain midazolam with no preservatives added.

All patients were observed for two hours in the recovery room before returning to the ward. Heart rate and pulse oximetry were monitored continuously and blood pressure was monitored every five minutes by an electronic oscillometer. When the child was awake in the recovery room, objective pain assessments, respiratory rate, blood pressure and heart rate were recorded by one investigator unaware of the patient's grouping. Assessments were made at 15 -min intervals for the first hour, 30 -min intervals for the second hour and 3, 4, 5, 6, and $24 \mathrm{hr}$ recovery from anaesthesia. The observer scored pain on each occasion with reference to a six-point scale (Table I) (none/insignificant pain (1-2); moderate pain (3-4); severe pain (5-6)), a modification of the pain/discomfort scale. ${ }^{22}$ Demeanour was scored with reference to a three-point scale (cheerful and calm; restless; tense or tearful). Side effects were recorded by the observer as well as the time at which, if any, analgesia was first received (recovery to first analgesic time), together with total number of analgesic doses required in the first 24 $\mathrm{hr}$ after operation. The patient's ability to stand unaided was assessed at six hours postoperatively.

On evidence of pain, that is if the pain score reached a value of $\geq 3$, children received a paracetamol suppository in a dose-related body weight (125-250 $\mathrm{mg}$ ) by the nursing staff, who were unaware of the group allocation of the patients.

Further assessment at $24 \mathrm{hr}$ postoperatively was made by nurses and mothers. They were asked to assess the child's behaviour at bed-time on the day of operation and on the following morning with respect to analgesia (acceptable or not) and quality of overnight sleep (good or interrupted).

\section{Data processing}

Exact Kruskal-Wallis test was used for comparisons among groups using StatXact-Turbo software (Cytel Software Corporation, Cambridge, MA, 1992). The times at which analgesia was given were treated as being analogous to survival data. "Survival" curves were plotted to indicate the proportion of patients in each group who had received no analgesia by a given time after operation using BMDP statistical package, release 7.1 (University of California Press, Berkeley, California, 1993). The times at which analgesia was first received for the three groups were compared using four nonparametric linear rank tests: the Mantel-Cox (log-rank), Tarone-Ware, Breslow, 
TABLE I Pain scale

\begin{tabular}{lll}
\hline Observation & Criteria & Points \\
\hline Crying & Not crying & 1 \\
& Crying but responds to tender loving care (TLC) & 2 \\
& Crying and does not respond to TLC & 3 \\
& & \\
Posture & No special posture & 1 \\
& Flexing legs and thighs & 2 \\
& Holding groin & 3 \\
\hline
\end{tabular}

TABLE II Patient data. Values are mean \pm SD (range)

\begin{tabular}{llll}
\hline & & & Bupivacaine \\
& group $(n=15)$ & $\begin{array}{l}\text { Midazolam } \\
\text { group }(n=15)\end{array}$ & $\begin{array}{l}\text { midazolam } \\
\text { group }(n=15)\end{array}$ \\
\hline Age (mo) & $54.8 \pm 13$ & $47.9 \pm 10.5$ & $52.2 \pm 14.2$ \\
& $(36-72)$ & $(30-60)$ & $(24-72)$ \\
Weight (kg) & $17 \pm 3$ & $15.9 \pm 2.4$ & $15.7 \pm 3.3$ \\
& $(13-23)$ & $(11-19)$ & $(9.2-22)$ \\
\hline
\end{tabular}

and Peto-Prentice statistics. These tests compare the observed rate at which patients needed analgesia with the rate which might be expected if caudal administration of bupivacaine, bupivacaine-midazolam and midazolam were equally effective. $P<0.05$ was regarded as statistically significant.

\section{Results}

The groups were comparable in age and weight (Table II). Caudal administration of bupivacaine with the addition of midazolam resulted in superior analgesia compared with the other two groups. The times at which analgesia was first received are displayed in the form of survival curves in Figure 1. The curves indicate the proportion of patients who received no analgesia by a given elapsed time since recovery from anaesthesia.

Recovery to first analgesic times was longer $(P<$ 0.001 ) in the bupivacaine-midazolam group than in the other two groups. In addition, the bupivacaine group received more doses $(P<0.05)$ of paracetamol than the bupivacaine-midazolam group in order to maintain analgesia in the first $24 \mathrm{hr}$ after recovery from anaesthesia (Table III).

In general, the quality of analgesia in the group which had received caudal injection of midazolam alone did not differ from other groups (Figure 2). There was no difference between the caudal midazolam group and the other two groups in the number of analgesic doses required in the first $24 \mathrm{hr}$.

Administration of midazolam caudally either alone or in combination with bupivacaine was not associated with changes in postoperative behaviour. In fact, more patients

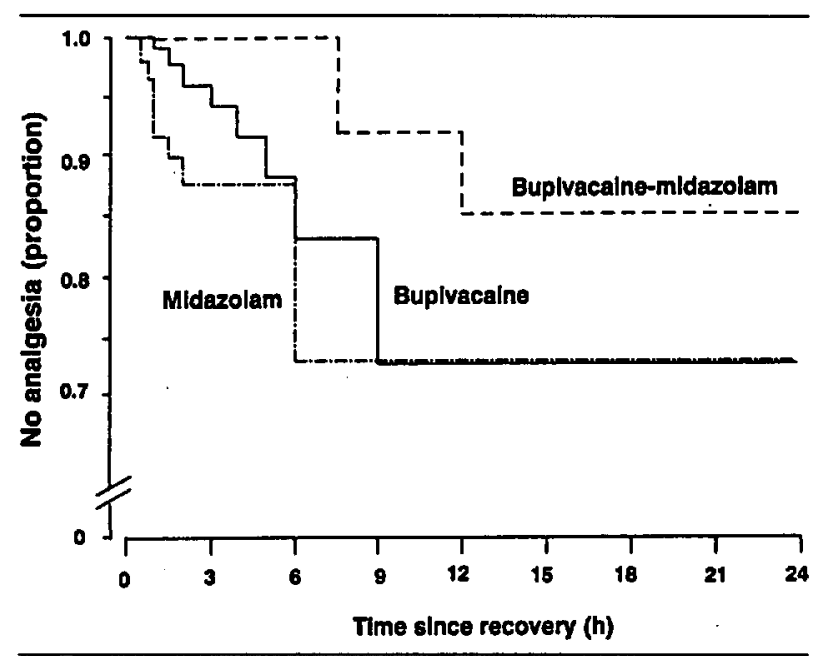

FIGURE 1 "Survival" curves for the bupivacaine ( $\longrightarrow$ ), midazolam (-..-. $)$ and bupivacaine-midazolam (----) groups. Proportion of patients in each group who had not required any analgesia since recovery from anaesthesia.

TABLE III Requirement for analgesia during the first $24 \mathrm{hr}$ after operation. Number (\%) of patients receiving 0-3 doses of paracetamol suppository

\begin{tabular}{llll}
\hline & \multicolumn{2}{l}{ Patients receiving analgesia } \\
\cline { 2 - 4 } $\begin{array}{l}\text { Analgesia } \\
\text { (No. of }\end{array}$ & Bupivacaine & Midazolam & $\begin{array}{l}\text { Bupivacaine- } \\
\text { midazolam }\end{array}$ \\
doses) & group $(n=15)$ & group $(n=15)$ & group $(n=15)(n)$ \\
\hline 0 & $7(46.7)$ & $7(46.7)$ & $13(86.7)$ \\
1 & $3(20)$ & $6(40)$ & $2(13.3)$ \\
2 & $4(26.7)$ & $2(13.3)$ & 0 \\
3 & $1(6.6)$ & 0 & 0 \\
\hline
\end{tabular}

* $P<0.05$ vs caudal bupivacaine group.

who had received caudal midazolam either alone or mixed with bupivacaine were described as cheerful and calm immediately after recovery from anaesthesia (Figure 3) than those in the bupivacaine group.

The results from mothers' and nurses' assessments 24 $\mathrm{hr}$ after operation showed no differences among the three group with respect to pain and quality of overnight sleep. Vomiting occurred postoperatively in two $(13.3 \%)$ and one $(6.6 \%)$ patient in the caudal bupivacaine and bupivacaine-midazolam groups respectively (NS). No patient in the midazolam group had any emetic sequalae. Four patients $(26.7 \%)$ in both bupivacaine and bupivacaine-midazolam groups were unable to stand at six hours postoperatively. In contrast, no patient in the caudal midazolam group had any sign of motor weakness.

No child had a recorded respiratory rate of less than 


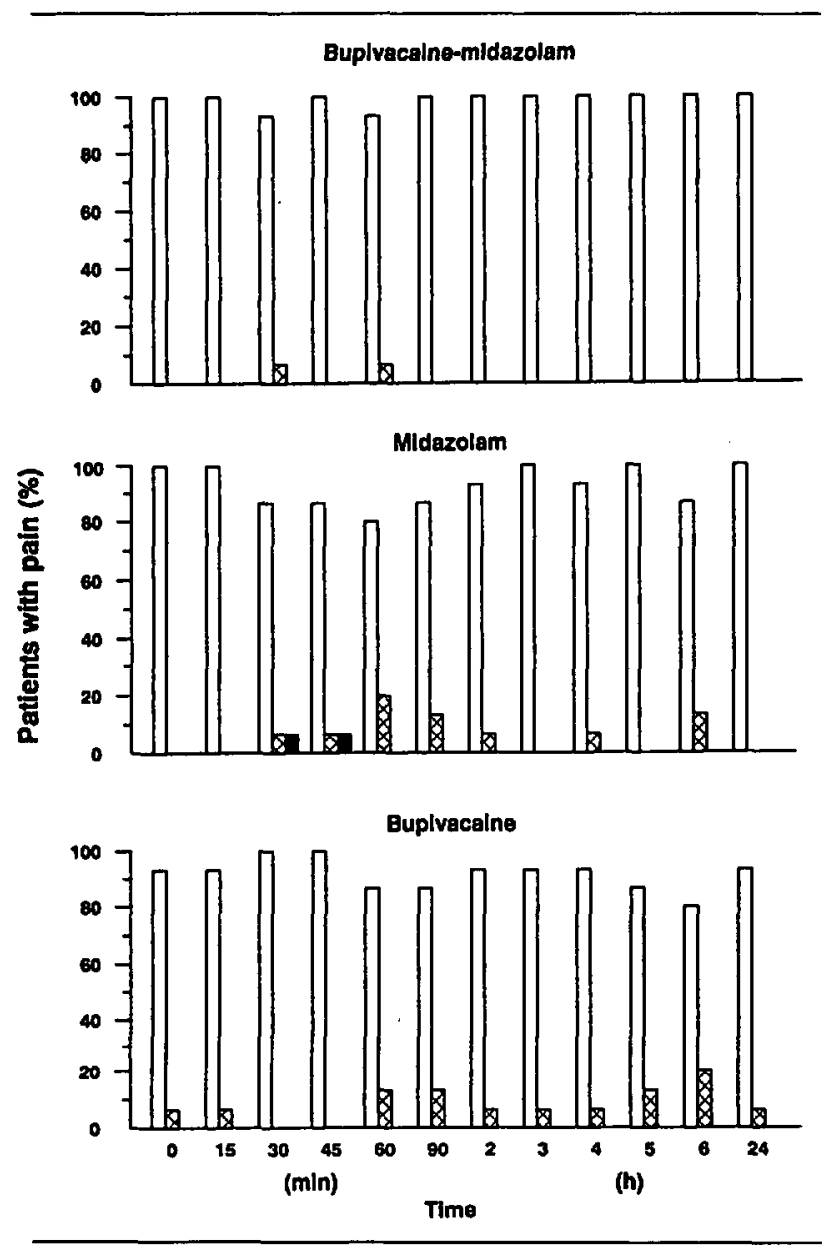

FIGURE 2 Incidence of postoperative pain in the first $24 \mathrm{hr}$ after recovery from anaesthesia. $\square=$ None/insignificant pain; $\$=$ moderate pain; $=$ severe pain.

12 bpm or showed any changes in heart rate and blood pressure in the first $24 \mathrm{hr}$ postoperatively. There were no instances of prolonged sedation, hypotension, bradycardia, residual paralysis, or toxic reactions to bupivacaine or midazolam during or after administration of caudal blocks.

\section{Discussion}

The results of the present study confirm and extend previous reports that epidural administration of midazolam exerts modulatory influences on postoperative pain mechanisms. In this study, caudal administration of midazolam $50 \mu \mathrm{g} \cdot \mathrm{kg}^{-1}$ in children produced postoperative analgesia comparable with that associated with caudal injection of $0.25 \%$ bupivacaine, $1 \mathrm{ml} \cdot \mathrm{kg}^{-1}$. In this study, $53 \%$ of patients in the caudal midazolam group and the bupivacaine group required additional analgesia during the first $24 \mathrm{hr}$ after surgery (Table III). These results are similar to those of a previous report on herniotomy, ${ }^{2,23}$

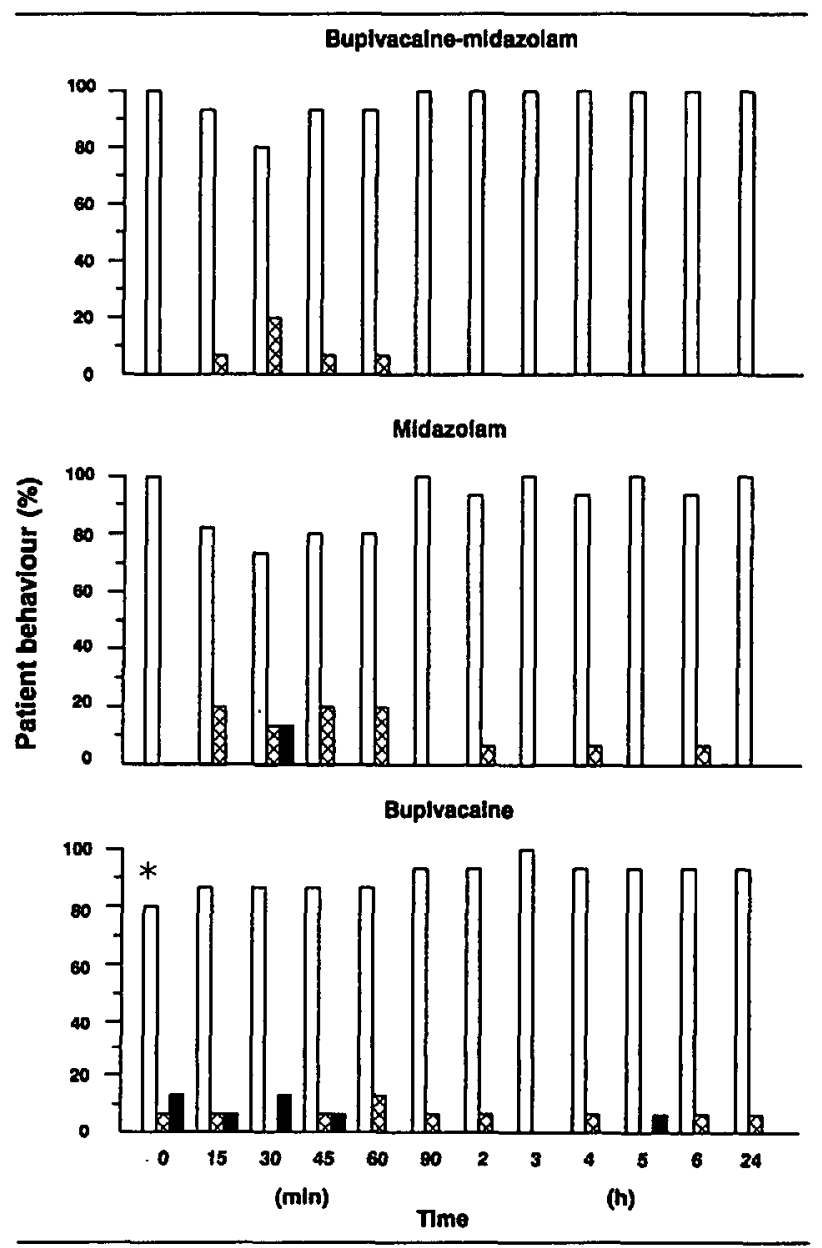

FIGURE 3 Postoperative behaviour in the first $24 \mathrm{~h}$ after recovery from anaesthesia. $\square=$ Calm and cheerful; $\nabla=$ restless; $\square=$ tense or tearful. $* P=0.029$ vs other groups.

in which $50-55 \%$ of patients who had caudal block with $0.25 \%$ bupivacaine $1 \mathrm{ml} \cdot \mathrm{kg}^{-1}$ required further analgesia.

The addition of midazolam $50 \mu \mathrm{g} \cdot \mathrm{kg}^{-1}$ to $0.25 \%$ bupivacaine $1 \mathrm{ml} \cdot \mathrm{kg}^{-1}$ improved caudal analgesia compared with that provided by bupivacaine alone, without an increase in the incidence of side effects. There was a reduction in the amount of postoperative analgesics required by the children in bupivacaine-midazolam group compared with those receiving bupivacaine alone (Table III). In addition, the recovery to first analgesic times were shorter $(P<0.001)$ in the former group (Figure 1).

Several families of spinal receptors are known to modulate the processing of nociceptive stimuli. Among these are the GABA receptors. ${ }^{11-15}$ The benzodiazepine receptor seems to be coupled to both the GABA receptor and the chloride channel in a GABA-benzodiazepine-receptorchloride-channel complex. The antinociceptive effects of intrathecal benzodiazepines are antagonized by the specific benzodiazepine antagonist (RO15-1788; flumazenil) 
but not by naloxone. ${ }^{15,24}$ In the dorsal horn of spinal cord, GABA receptors on primary afferent terminals mediate presynaptic inhibition. At these endings, GABA produces a mild depolarization of the primary afferent and thereby can reduce the release of the excitatory transmitter onto second-order neurons in the spinal cord and brain stem. ${ }^{25}$ Beside the effect of midazolam on the benzodiazepine-GABA ionophore complex, pharmacological properties, other than modulation of the function of $\mathrm{GABA}_{\mathrm{A}}$ receptors, have also been described. These properties provide possible ways of modifying the processing of spinal pain without an interaction with the $\mathrm{GABA}_{\mathrm{A}}$ receptor. First, midazolam has been shown to inhibit the reuptake of GABA from synaptosomes from brain. ${ }^{26}$ Secondly, Hunkeler et al. ${ }^{25}$ noted that the binding of the benzodiazepine agonists to the benzodiazepine receptor is enhanced by GABA itself. Thirdly, benzodiazepine receptor agonists in cultured neurons of the spinal cord depolarize the cell and elevate the absolute threshold for the generation of action potentials. ${ }^{27}$

In humans, midazolam, administered intrathecally before abdominal or leg surgery, partially blocked pain evoked by somatic but not by visceral stimuli. ${ }^{17}$ Extradural administration of midazolam to postoperative adult patients ${ }^{18}$ and individuals with chronic pain resulted in significant analgesia. ${ }^{16,19,20}$ Nishiyama et al. ${ }^{28}$ evaluated four doses $\left(25,50,75\right.$ and $\left.100 \mu \mathrm{g} \cdot \mathrm{kg}^{-1}\right)$ of epidural midazolam mixed with saline in patients undergoing upper abdominal surgery. They concluded that midazolam 50 $\mu \mathrm{g} \cdot \mathrm{kg}^{-1}$ was the optimal dose for postoperative analgesia. Higher doses were associated with prolonged and deep sleep (patients were not responding to verbal command).

In this study, caudal blocks were performed at the end of surgery. Based on animal studies, ${ }^{29}$ it has been suggested that pre-emptive administration of regional anaesthesia to patients might reduce postoperative pain to a greater extent than postoperative administration. ${ }^{30}$ However, several studies have failed to demonstrate any advantages of pre-emptive analgesia ${ }^{31-34}$ (for review see Woolf and Chong ${ }^{35}$ ). In fact, Holthusen et al. ${ }^{34}$ failed to demonstrate any advantage in performing caudal block before, compared with after, surgery in children.

Many investigators have postulated a synergistic analgesic effect of local anaesthetic agents and opioids when given intrathecally or epidurally. Intrathecal or epidural combinations of bupivacaine and morphine were found to produce better analgesia in women in labour than the administration of either drug alone. ${ }^{36,37}$ However, little objective evidence has been presented to quantitate such an effect or to explain the mechanism of synergy. Tejwani et al. ${ }^{38}$ found in the rat that bupivacaine potentiated the antinociception produced by intrathecal administration of
$10 \mu \mathrm{g}$ morphine. At higher doses of morphine $(20 \mu \mathrm{g})$, bupivacaine decreased the total duration of morphineinduced antinociception. They also noted that the binding of opioid ligands to all spinal receptors was inhibited at high doses of bupivacaine. ${ }^{38}$ Therefore, the extent of the interactions between these two drugs depends upon their relative concentration at the site of action. This could explain the absence of synergism between bupivacaine and midazolam combination in this study. Further, it has been shown that the addition of bupivacaine does not enhance the postoperative analgesia in orthopaedic surgery patients receiving continuous epidural fentanyl. ${ }^{39,40}$ It should be noted, however, that the exact nature of drug interaction cannot be determined from a single combination. It requires knowledge of the exact amounts of a series of mixtures of two drugs needed for the quantitatively specified effect.

The overall incidence of side effects observed in the bupivacaine and bupivacaine-midazolam groups was comparable with previous reports in children who received caudal bupivacaine. ${ }^{2,28,41}$ Prolonged sedation was noted following extradural administration of midazolam $75-100 \mu \mathrm{g} \cdot \mathrm{kg}^{-1} .{ }^{18,27}$ This large dose of midazolam may have resulted in rostral migration of significant quantities of drug into the supraspinal areas. In contrast, in the present study, we did not observe any prolonged somnolence or sedation following caudal administration of midazolam $50 \mu \mathrm{g} \cdot \mathrm{kg}^{-1}$. In fact, the administration of midazolam caudally either alone or in combination with bupivacaine was not associated with changes of postoperative behaviour (Figure 3). In accordance with other reports, ${ }^{16-20}$ we noted that caudal midazolam was not associated with respiratory depression or motor block, and rapid mobilization was possible in that group.

Animal studies demonstrated a lack of deleterious effect on spinal function or morphologic features after subarachnoid midazolam. ${ }^{20,21}$ No signs of toxicity of midazolam on the spinal cord or the meninges were found in the rat after constant subarachnoid administration of midazolam (50 $\mu \mathrm{g}$ per day) for 15 days. ${ }^{20}$ Similar observations were noted in rabbits. ${ }^{21}$ Only after administration of very large doses of midazolam intracisternally in rabbits $\left(0.3 \mathrm{ml}\right.$ of $0.1 \%$; equivalent to $\left.111 \mu \mathrm{g} \cdot \mathrm{kg}^{-1}\right)$ were changes in blood-brain barrier observed. ${ }^{42} \mathrm{It}$ is well known that even high concentrations of lidocaine are believed to possess neurotoxic effects in humans. ${ }^{43,44}$ The safety of neuraxial administration of midazolam in humans has been demonstrated by several investigators. ${ }^{16-19,28}$

We conclude that caudal administration of midazolam in a dose of $50 \mu \mathrm{g} \cdot \mathrm{kg}^{-1}$ provides equivalent analgesia to bupivacaine $0.25 \%$, when administered postoperatively in a volume of $1 \mathrm{ml} \cdot \mathrm{kg}^{-1}$ to children after unilateral 
inguinal herniotomy, without respiratory depression or other side effects.

\section{References}

1 LLoyd-Thomas $A R$. Pain management in paediatric patients. Br J Anaesth 1990; 64: 85-104.

2 Naguib $M$, Sharif AMY, Seraj $M$, El Gammal M, Dawlatly $A A$. Ketamine for caudal analgesia in children: comparison with caudal bupivacaine. $\mathrm{Br} \mathrm{J}$ Anaesth 1991; 67: 559-64.

3 Desparmet JF. Total spinal anesthesia after caudal anesthesia in an infant. Anesth Analg 1990; 70: 665-7.

4 Krane EJ, Tyler DC, Jacobson LE. The dose response of caudal morphine in children. Anesthesiology 1989; 71: 48-52.

5 Krane EJ. Delayed respiratory depression in a child after caudal epidural morphine. Anesth Analg 1988; 67: 79-82.

6 Racle JP, Benkhadra A, Poy JY, Gleizal B. Prolongation of isobaric bupivacaine spinal anesthesia with epinephrine and clonidine for hip surgery in the elderly. Anesth Analg 1987; 66: 442-6.

7 Lee JJ, Rubin AP. Comparison of a bupivacaine-clonidine mixture with plain bupivacaine for caudal analgesia in children. Br J Anaesth 1994; 72: 258-62.

8 Möhler H, Okada T. Benzodiazepine receptor: demonstration in the central nervous system. Science 1977; 198: 849-51.

9 Doble A, Martin IL. Multiple benzodiazepine receptors: no reason for anxiety. Trends Pharmacol Sci 1992; 13: 76-81.

10 Möhler $H$, Okada $T$. The benzodiazepine receptor in normal and pathological human brain. Br J Psychiatry 1987; 133: 261-68.

11 Unnerstall JR, Kuhar MJ, Niehoff DL, Palacios JM. Benzodiazepine receptors are coupled to a subpopulation $\gamma$-aminobutyric acid (GABA) receptors: evidence from a quantitative autoradiographic study. J Pharmacol Exp Ther 1981; 218: 797-804.

12 Nistri A, Berti $C$. Influence of benzodiazepines of GABAevoked responses of amphibian brain and spinal neurons in vitro. Neuropharmacology 1984; 23: 851-2.

13 Niv D, Whitwam JG, Loh $L$. Depression of nociceptive sympathetic reflexes by the intrathecal administration of midazolam. Br J Anaesth 1983; 55: 541-7.

14 Serrao JM, Stubbs SC, Goodchild CS, Gent JP. Intrathecal midazolam and fentanyl in the rat: evidence for different spinal antinociceptive effects. Anesthesiology 1989; 70: 780-6.

15 Yanez A, Sabbe MB, Stevens $C W$, Yaksh $T L$. Interaction of midazolam and morphine in the spinal cord of the rat. Neuropharmacology 1990; 29: 359-64.

16 Rigoli $M$. Epidural analgesia with benzodiazepines. In: Tiengo M, Cousins MJ (Eds.). Pharmacological Basis of
Anesthesiology: Clinical Pharmacology of New Analgesics and Anesthetics. New York: Raven Press, 1983: 69-76.

17 Goodchild CS, Noble $J$. The effects of intrathecal midazolam on sympathetic nervous system reflexes in man - a pilot study. Br J Clin Pharmacol 1987; 23: 279-85.

18 Nishiyama T, Odaka Y, Hirasaki A, Seto K. Epidural midazolam for treatment of postoperative pain. Masui 1991; 40: 1353-8.

19 Serrao JM, Marks RL, Morley SJ, Goodchild CS. Intrathecal midazolam for the treatment of chronic mechanical low back pain: a controlled comparison with epidural steroid in a pilot study. Pain 1992; 48: 5-12.

20 Schoeffler P, Auroy P, Bazin JE, Taxi J, Woda A. Subarachnoid midazolam: histologic study in rats and report of its effect on chronic pain in humans. Reg Anesth 1991; 16: 329-32.

21 Auroy P, Schoeffler P, Maillot C, Haberer JP, Woda A. Tolérance intrathécale du midazolam. Etude histologique. Ann Fr Anesth Reanim 1988; 7: 81-2.

22 Broadman LM, Hannallah RS, Belman AB, Elder PT, Ruttimann U, Epstein BS. Post-circumcision analgesia - a prospective evaluation of subcutaneous ring block of the penis. Anesthesiology 1987; 67: 399-402.

23 Fell D, Derrington MC, Taylor E, Wandless JC. Paediatric postoperative analgesia. A comparison between caudal block and wound infiltration of local anaesthetic. Anaesthesia 1988; 43: 107-10.

24 Hunkeler W, Möhler $H$, Pieri $L$, et al. Selective antagonists of benzodiazepines. Nature 1981; 290: 514-6.

25 Haefely WE. Benzodiazepines. Int Anesthesiol Clin 1988; 26: 262-72.

26 Cheng $S-C$, Brunner EA. Inhibition of GABA metabolism in rat brain synaptosomes by midazolam (RO-21-3981). Anesthesiology 1981; 55: 41-5.

27 Haefely $W$, Polc $P$. Physiology of GABA enhancement by benzodiazepines and barbiturates. In: Olsen RW, Venter JC (Eds.). Benzodiazepine/GABA Receptors and Chloride Channels: Structural and Functional Properties. New York: Liss, 1986: 97-133.

28 Nishiyama T, Hirasaki A, Odaka $Y$, Konishi H, Seto K, Goto $I$. Epidural midazolam with saline - optimal dose for postoperative pain. Masui 1992; 41: 49-54.

29 Dickenson AH, Sullivan AF. Subcutaneous formalininduced activity of dorsal horn neurones in the rat: differential response to an intrathecal opiate administered pre or post formalin. Pain 1987; 30: 349-60.

30 Woolf CJ. Recent advances in pathophysiology of acute pain. Br J Anaesth 1989; 63: 139-46.

31 Dierking GW, Dahl JB, Kanstrup J, Dahl A, Kehlet H. Effect of pre- $v s$ postoperative inguinal field block on postoperative pain after herniorrhaphy. Br J Anaesth 1992; 68: 344-8.

32 Dahl JB, Hansen BL, Hjorts $\varnothing$ NC, Erichsen CJ, Møiniche 
$S$, Kehlet $H$. Influence of timing on the effect of continuous extradural analgesia with bupivacaine and morphine after major abdominal surgery. Br J Anaesth 1992; 69: 4-8.

33 Pryle BJ, Vanner RG, Enriquez N, Reynolds F. Can preemptive lumber epidural blockade reduce postoperative pain following lower abdominal surgery? Anaesthesia 1993; 48: 120-3.

34 Holthusen H, Eichwede F, Stevens $M$, Willnow U, Lipfert $P$. Pre-emptive analgesia: comparison of preoperative with postoperative caudal block on postoperative pain in children. Br J Anaesth 1994; 73: 440-2.

35 Woolf CJ, Chong M-S. Preemptive analgesia - treating postoperative pain by preventing the establishment of central sensitization. Anesth Analg 1993; 77: 362-79.

36 Abouleish E, Rawal N, Shaw J, Lorenz T, Rashad N. Intrathecal morphine $0.2 \mathrm{mg}$ versus epidural bupivacaine $0.125 \%$ or their combination: effects on parturients. Anesthesiology 1991; 74: 711-6.

37 Abboud TK, Afrasiabi A, Zhu J, et al. Epidural morphine or butorphanol analgesia during labor. Reg Anesth 1989; 14: 115-20.

38 Tejwani GA, Rattan AK, McDonalds JS. Role of spinal opioid receptors in the antinociceptive interactions between intrathecal morphine and bupivacaine. Anesth Analg 1992; 74: 726-34.

39 Loper KA, Ready LB, Downey M, et al. Epidural and intravenous fentanyl infusions are clinically equivalent after knee surgery. Anesth Analg 1990; 70: 72-5.

40 Badner NH, Reimer EJ, Komar WE, Moote CA. Lowdose bupivacaine does not improve postoperative epidural fentanyl analgesia in orthopedic patients. Anesth Analg 1991; 72: 337-41.

41 Wolf $A R$, Valley $R D$, Fear $D W$, Roy WL, Lerman J. Bupivacaine for caudal analgesia in infants and children: the optimal effective concentration. Anesthesiology 1988; 69: 102-6.

42 Malinovsky J-M, Cozian A, Lepage J-Y, Mussini J-M, Pinaud $M$, Souron $R$. Ketamine and midazolam neurotoxicity in the rabbit. Anesthesiology 1991; 75: 91-7.

43 Rigler ML, Drasner K, Krejcie TC, et al. Cauda equina syndrome after continuous spinal anesthesia. Anesth Analg 1991; 72: 275-81.

44 Drasner $K$. Models for local anesthetic toxicity from continuous spinal anesthesia. Reg Anesth 1993; 18; 434-8. 